$11-15-2013$

\title{
Reconfiguring the War and Family Tropes in Thaw-Era Homefront Melodrama
}

Alexander V. Prokhorov

College of William \& Mary, axprok@wm.edu

Follow this and additional works at: https://scholarworks.wm.edu/asbookchapters

Part of the Film and Media Studies Commons, Modern Languages Commons, and the Slavic Languages and Societies Commons

\section{Recommended Citation}

Prokhorov, A. V. (2013). Reconfiguring the War and Family Tropes in Thaw-Era Homefront Melodrama. Rimgaila Salys (Ed.), The Russian Cinema Reader: Volume II, The Thaw to the Present (pp. 37-52). Academic Studies Press. https://scholarworks.wm.edu/asbookchapters/85 


\title{
RECONFIGURING THE WAR AND THE FAMILY TROPES IN THAW-ERA HOMEFRONT MELODRAMA
}

\author{
Alexander Prokhorov
}

The Cranes Are Flying underscores the dominant narrative of homefront melodrama during the Thaw: the reconstitution of the nuclear family around the trauma of irrecoverable loss generated by war. Unlike the melodramas of the era that primarily focus on the reconstitution of the troubled family, Cranes shifts the focus to the war experience of the most powerless and sinful member of the community: the unfaithful woman. ${ }^{1}$

In Thaw-era home-front melodrama, war's significance as the cause of loss and instability becomes an ambiguous signifier because the victimizer is usually not an external enemy but a sadistic "us." Kalatozov's melodrama reconfigured the war trope inherited from Stalinism, transforming the ideological confrontation between "us" and "them" into a conflict between the female protagonist and the war equated with familial "us." War victimizes the disempowered, orphaned, and fallen Veronika. Her individual feminine experience becomes the locus of Thaw-era values.

Films of the Thaw period emphasized the visualization of the protagonist's sufferings. The resurrection of visual expressivity in post-Stalinist film made camera work critical for Thaw-era filmmaking, and Kalatozov owes much of the success of Cranes to his cameraman Sergei Urusevskii. ${ }^{2}$ My discussion of Cranes concentrates

1 The most representative family melodramas of the Thaw period are Big Family (Kheifits, 1953), The Unfinished Story (Ermler, 1955), The House I Live In (Kulidzhanov and Segel, 1957), Ekaterina Voronina (Anninskii, 1957), and My Beloved (Kheifits, 1958).

2 In Russian film histories, as well as in the works favoring an auteur approach in general, the director is usually mentioned as the main author of the film. The only exceptions are 1920s avant-garde film and Thaw-era cinema. Two famous cameramen of the Thaw period are Sergei Urusevskii, who worked 
on the elements of its structure that contributed to post-Stalinist reimagining of both the war and the family tropes: the protagonist's characterization through the uses of mise-en-scène and camera, the personalized temporality of war, and the family structure.

Cranes not only problematizes the conventions of Stalinist melodrama, but also defines the protagonist, Veronika, against the background of ideal Stalinist womanhood, as envisioned by views during the Thaw. Veronika's foil, Boris's older sister Irina, incarnates this ideal: she is articulate, reason-driven, sexually repressed, and dressed in a military uniform. Kalatozov, however, presents Irina's model of femininity as unfit for the Thaw's envisioned new deal. The military uniform, a low masculine voice, and military body language are presented as a gender mismatch. Irina's father even complains that in being a successful surgeon his daughter made only one mistake-she was born a female. The primacy of reason at the expense of emotionality is presented by the filmmakers as Irina's deficiency of sensitivity. Moreover, Irina's repressed sexuality is channeled into sadistic energy, used to torment the victimprotagonist of the film.

\section{Visual Style and Expressive Mise-en-Scène}

The expressive mise-en-scène of The Cranes Are Flying makes visible the protagonist's inner suffering, which supports Mary Ann Doane's argument that the distinctive feature in the structure of the melodramatic character is "the externalization of internal emotions

with Kalatozov, and Vadim Iusov, who collaborated with Andrei Tarkovskii. Sergei Urusevskii's contribution to Soviet cinema is usually discussed within the context of reviving the tradition of the 1920s avant-garde film. See Iurii Bogomolov, Mikhail Kalatozov: Stranitsy tvorcheskoi biografii (Moscow: Iskusstvo, 1989), 157-61; Antonin Liehm and Mira Liehm, The Most Important Art: Soviet and East European Film after 1945 (Berkeley: University of California Press, 1977), 199-200; and Maiia Merkel', Ugol zreniia: Dialog s Uruserskim (Moscow: Iskusstvo, 1980), 32.

Intelligentsia of the Thaw period also associated avant-garde film with black-and-white film stock, and late Stalinist film with excessive use of color. This was the other reason that many Thaw-era family melodramas avoided color and used avant-garde film techniques to convey melodramatic excess. 
and their embodiment within the mise-en-scène." ${ }^{3}$ In characteristic family melodrama fashion, Veronika's body is especially important, because she, unlike the Stalinist ideal female, has a weak command of language. ${ }^{4}$ Tania Modleski notes that "many of the classic film melodramas from the 30 s through the 50 s are peopled by ... women possessed by an overwhelming desire to express themselves ... but continually confronting the difficulty, if not the impossibility to realize the desire." ${ }^{5}$ This observation accurately describes the dilemmas confronting Veronika, who cannot give form to her sufferings through language and painfully searches for alternative channels of self-expression. At the beginning of the film, Veronika either asks questions or speaks in incomplete sentences. The best example of her inarticulateness is a song about cranes, which Veronika sings at the beginning of the film.

The long-billed cranes

Are flying overhead,

Gray ones, white ones,

Ships in the skies. ${ }^{6}$

In this fragment, the narrative or facts fade into irrelevance, as the value of mood and emotion replaces them.

Veronika lacks the paternal source of discourse available to Stalinist women. All the males who could potentially empower her with their ideologically impeccable logos disappear from the

3 Mary Ann Doane, "The Moving Image: Pathos and the Maternal," 285, in Imitations of Life: A Reader on Film and Television Melodrama, ed. Marcia Landy (Detroit: Wayne State University Press, 1991).

4 Marcia Landy and Amy Villarejo point out that a "mute quality" is one of the major characteristics of melodrama: "The verbal language is inadequate to the affect that melodrama seeks to communicate" (Landy and Villarejo, Queen Christina [London: British Film Institute, 1995], 27).

5 Tania Modleski, “Time and Desire in the Women's Film,” 537, in Film Theory and Criticism, ed. Gerald Mast, Marshall Cohen, and Leo Braudy (NY: Oxford University Press, 1992).

6 Viktor Rozov, "Alive Forever," in Contemporary Russian Drama (NY: Pegasus, 1968), 24. 
narrative. Veronika loses her biological father and her fiancé in the first months of the war. The discourses offered by the other two male characters, Mark and Fedor, are corrupt. Mark is unfaithful and constantly lies to Veronika. When Fedor Ivanovich pronounces his diatribe against unfaithful women, he adopts the official discourse and pushes Veronika toward a suicide attempt-after his speech Veronika decides to jump off the bridge under a train. ${ }^{7}$

Being inept at verbal language, Veronika retreats to the language of emotional bodily gesture, which the film promotes to the status of natural language. ${ }^{8}$ Body language provides the most efficient way to convey the inner self. Tellingly, at the beginning of the film Veronika and Boris agree on the time of their next date by using fingers instead of words (Fig. 77): more precisely, Boris speaks while Veronika uses her hands.

Other characters who share the protagonist's sincerity also favor emotional gesture over corrupt, reason-driven speech. When Fedor, for example, tries to explain why his son has to go to war he cannot find the appropriate words, and he starts crying and drinks a shot of alcohol. When Boris's friend Volodia jokes about the likelihood of Veronika's being unfaithful to him, Boris also abandons words and uses his fists as a means of communication. When Volodia realizes that he mistakenly has told Veronika about Boris's death, speech fails him, and instead he kisses her wet hand covered with soap.

Although Veronika's bodily gestures create a sincere discourse beyond the corrupt word, Veronika's body also becomes a major site of war trauma, conveyed through two major elements of miseen-scène: lighting and the color of her clothing. Veronika's clothes create a polarized realm of white and black. The two colors signal

7 As Richard Stites notes, it was a literary reference that "no Russian could miss" (Stites, Russian Popular Culture: Entertainment and Society since 1900 [Cambridge: Cambridge University Press, 1992], 141).

8 Discussing the reactions of Diderot and Rousseau to the Enlightenment crisis, Peter Brooks notes: "Gesture appears in the Essai to be a kind of pre-language, giving a direct presentation of things prior to the alienation from presence set off by the passage into articulated language" (Brooks, "The Melodramatic Imagination," 66, in Imitations of Life). 


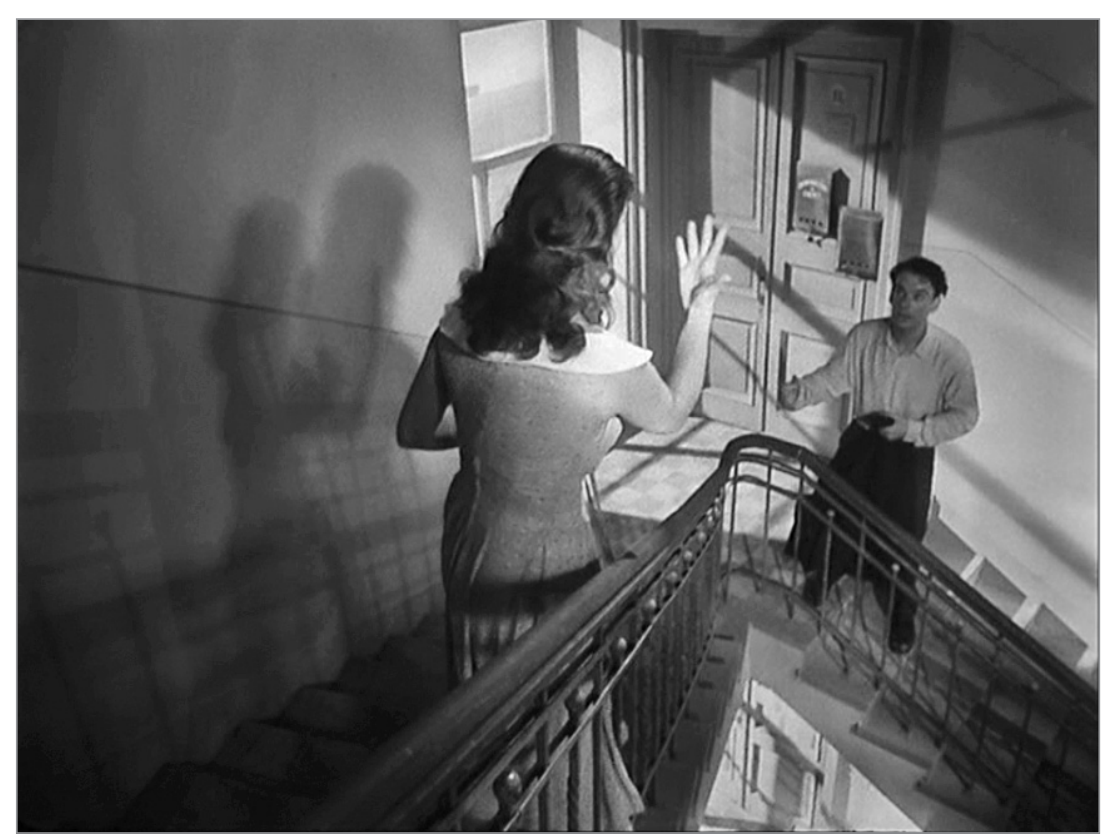

Fig. 77. Veronika and Boris

the protagonist's fall and resurrection as parts of the hyperbolized melodramatic world, where, according to Peter Brooks, every dress change "has little to do with the surface realities of a situation, and much more to do with the inner drama in which consciousness must purge itself and assume the burden of moral sainthood." ${ }^{9}$ Veronika's black-and-white clothes serve as the ultimate surface signifier exteriorizing her inner conflict.

Kalatozov's second mode of inscribing visual trauma on Veronika's body is through his use of lighting. In Wait for Me the bright light on Liza's face and blonde hair underscores her fidelity and perseverance amid the darkness of war, whereas the onset of war in Cranes covers the face of the protagonist in shadows. The shadows emphasize her vulnerability and anticipate the brutality of war. Once the war begins, the bright high-key lighting disappears from the film.

9 Brooks, “The Melodramatic Imagination,” 53. 
During Boris and Veronika's last meeting, shadows envelop them and only their eyes are highlighted by bright patches (Fig. 78). The ominous potential of shadow receives full realization in the rape scene, when the flashes of bomb explosions cast grotesque shadows on the protagonist's body. The rape experience is visualized as patches of black on Veronika's face, in a conflation of national and bodily invasion. The thinner and lighter shadows in the second part of the film signal Veronika's gradual recovery from the rape of war. The concluding scene, however, represents but does not resolve the contradiction between personal loss and common victory. The highkey, bright light shining over the celebratory crowd contrasts with the darkness of Veronika's eyes and hair.

To represent the protagonist's emotional state, Kalatozov employs Vsevolod Pudovkin's notion of "plastic material," that is, "those forms and movements that shall most clearly and vividly express in the images the whole content of the idea." 10 In Cranes such plastic material carries extraordinary emotional weight. For example, the stuffed squirrel that Boris gives to Veronika, whose nickname is "Squirrel," materializes the characters' emotional state (love, grief) or implies the generation of intense emotions (signaling betrayal, resurrection). Passed on to Veronika as Boris's birthday gift to her, the squirrel transforms into a symbol of their love after his departure. After Mark rapes and then marries Veronika, he steals the squirrel and presents it as a birthday gift to his mistress, thereby transforming the squirrel into an antithetical symbol, that of betrayal. When the stuffed squirrel is returned to Veronika and she belatedly reads the birthday card from Boris hidden inside it, the stuffed toy (an extremely antimonumental object) comes to symbolize the promise of Veronika's resurrection.

A distinctive feature of Thaw-era melodrama's setting, and that of Cranesin particular, is the subordination of space to the temporality of lateness, separation, and loss. Cranes is radically different in this respect from Stalinist works that favor spatial metaphors of war. In

10 Vsevolod Pudovkin, Film Technique and Film Acting (NY: Grove Press, 1949), 55. 


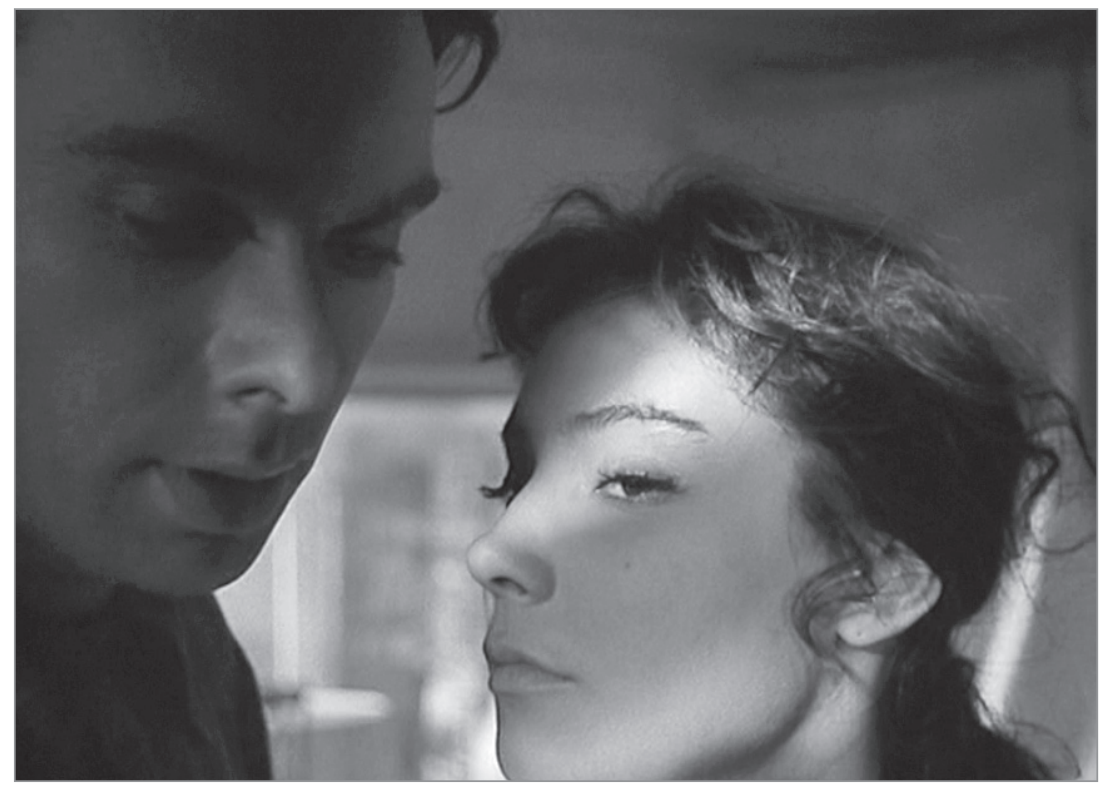

Fig. 78. The Last Meeting

the war-era melodrama Wait for Me (Zhdi menia, dir. Alexander Stolper, 1943), Liza searches for her husband on a map in a room where numerous portraits depict Stalin with maps and battle plans. By contrast, Thaw-era homefront melodrama allows time "out of joint" to dominate the space of the film. War becomes a time of personal tragedy instead of an epic space for a monumental battle.

Temporality dominates space, starting from the initial frame showing the film's title, which appears against the background of the clock on the main Kremlin tower. Clock sounds and images constantly remind the viewer about war as a time of loss. The clock chime of the radio foreshadows the announcement of war. When viewers hear the radio signal, they see Boris's empty chair at the family table. The family clock ticks deafeningly when Veronika opens the door into the abyss of her apartment, which has been destroyed by a bomb.

If time signifies the personal tragedy of war, then Veronika's recovery from the trauma is conveyed through the images of the protagonist transgressing the spatial borders that separate her from other people. To represent visually the protagonist's ordeal, 
Kalatozov favors two types of spatial composition within the film's shots: a space marked by dividing and separating lines and borders, and a space dominated by the protagonist's motion across them. The divided space appears more often in the first part of the film until Veronika's suicide attempt (note, for example, the farewell scene shots, where the prison-like bars of the steel fence separate Boris and Veronika).

The film contrasts such divided frames and claustrophobic rooms with transitional spaces, in which the protagonist experiences radical transformations. Mikhail Bakhtin has argued that "on the threshold ... the only time possible is crisis time, in which a moment is equal to years."11 The crisis/threshold chronotope precisely characterizes the emotional intensity of Veronika's existence in the transitional spaces. Her arrival in such a space indicates her extreme emotional state and the drastic change in her life. Among various types of such spaces, two are of decisive importance for the construction of the protagonist and her relationship to the war: bridges and staircases.

A bridge serves as the space of psychological/spiritual transition to Veronika's resurrection and reconciliation with the losses of war. Veronika comes to the bridge to save the life of an orphan and thereby saves her own soul. At film's end, Veronika crosses the bridge in an attempt to come to terms with her loss. Likewise, the three stair sequences provide transitional spaces in which characters experience the unavoidability of war suffering en route to their eventual salvation. The stairs spatially symbolize the death-shadowed time of war as the inversion of life's temporality. Consequently, the living characters move counterclockwisethat is, against the time of war-while the dead characters move clockwise, in tune with the temporality of death. Significantly, both Boris and Veronika favor an ascending motion, associated with a reconstitution of their "moral sainthood."12 Stairs belong to

11 Mikhail Bakhtin, Problems of Dostoevskii's Poetics (Minneapolis: University of Minnesota Press, 1984), 169-70.

12 Brooks, “The Melodramatic Imagination," 53. 
Fig. 79.

World Turned

Upside Down

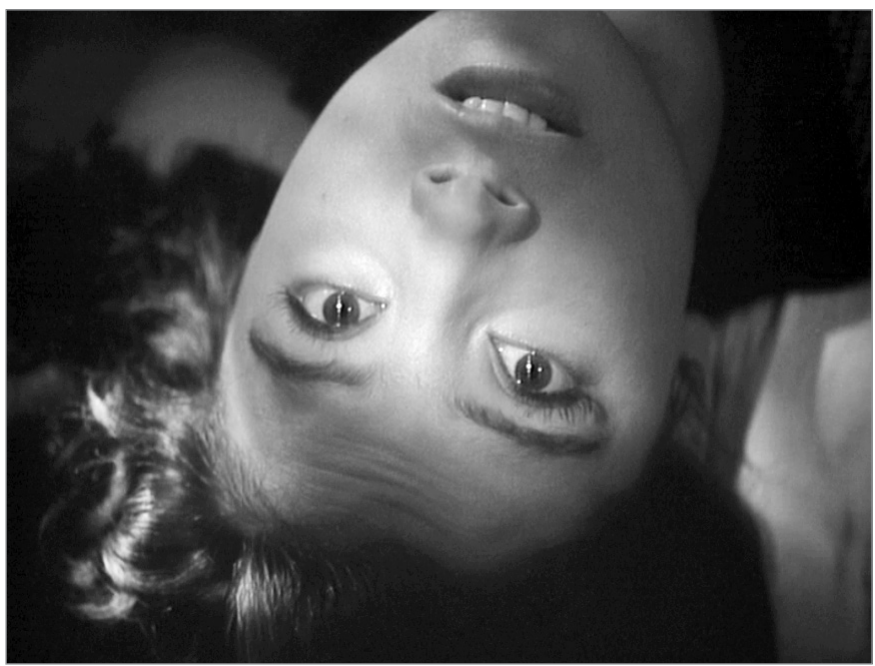

the vertical axis of Thaw-era melodrama, linking the earthly and heavenly worlds.

The camera's primary function in Cranes, like that of the miseen-scène, is to create the melodramatic protagonist. If mise-en-scène employs the protagonist's excessive bodily gestures to represent the sincerity and uniqueness of her emotions, then the camera employs close-ups for the same end. Close-up shots focus mainly on Veronika. They foreground and validate the sufferings of the most disempowered and marginalized member of the film's social and family hierarchy - a raped orphan. Moreover, to obliterate the significance of the background, cinematographer Urusevskii often used short-focused lenses and blurs the background of his closeups. ${ }^{13}$

The camera emphasizes the intensity of Veronika's emotions by tilting her face in the frame, disrupting the tonal homogeneity of the image with shadows and placing an obstacle between the

13 Several critics identify short-focused optics as a distinctive feature of the film's style. See Leonid Kosmatov, “Sovershenstvuia khudozhestvennuiu formu," Iskusstvo kino 12 (1957): 26; Neia Zorkaia, The Illustrated History of Soviet Cinema (London: Hippocrene Books, 1989), 212; and Bordwell and Thompson, Film Art: An Introduction (NY: McGraw-Hill, 1997), 216. 
protagonist's face and the viewer's gaze. An upside-down closeup indicates the destruction of peace-time norms and hierarchies (Fig. 79). Urusevskii presents through a carnivalesque close-up the ultimate trauma of the protagonist as Mark rapes her.

The close-ups conveying emotional excess also serve an important narrative function. They break the linear flow of the narrative and usually frame sequences designed to evoke pathos. For example, the sequence of Veronika's rape and Boris's death opens with a close-up of Veronika's face and ends with a closeup of Boris in the throes of death. His dead eyes acquire a glasslike quality, echoing the image of broken glass on the floor of the room where Veronika was raped. Serving as a framing device of the sequences dominated by extreme feelings, close-ups emphasize emotional intensity as the distinctive trait of the protagonist.

To convey the intensity of the protagonist's emotions, Urusevskii also employs extremely long tracking or panning shots. ${ }^{14}$ For example, he structures the concluding scene, in which Veronika runs to see Boris's friend Stepan, from whom she learns about her beloved's death, as a combination of radically extended tracking shots of Veronika. The temporal excessiveness of the tracking shots underscores Veronika's passionate hope, while the abrupt cut to a close-up of her and Stepan visually captures her despair when she learns about Boris's death. To impede the narrative flow and to intensify the emotional excess of the episode, the filmmakers also use real time in their long tracking shots, the effect of which is described here by critic Vitalii Troianovskii: "The extra-long tracking shot filmed in real time goes on and on. And you suddenly feel choked up from your proximity to another's soul."15 If the closeups emphasize the authenticity of suffering, then the length of the takes underscores the scope of individual trauma.

14 Russian works on Urusevskii's art call these long takes superpanorama, no matter whether they are pans or tracking shots. See Maiia Merkel', Ugol zreniia; and Vitalii Troianovskii, "Letiat zhuravli tret' veka spustia," Kinovedcheskie zapiski 17 (1993): 54.

15 Troianovskii, "Letiat zhuravli tret' veka spustia," 54. 
Finally, the third important camera device is the use of unconventional angles, extremely high and low, to represent the protagonist's psychological state. In the introductory part of the film, high-angle crane shots suggest the scale of the lovers' happiness through the openness and expanse of space. Shifts to low-angled shots focusing on the couple foreground the significance of their togetherness. With the beginning of the war, the high-angled shots gradually disappear and the closed form conveys the claustrophobic nature of Veronika's space. She lives in the attic, where the camera's eye is always confronted with objects blocking the view, thereby creating an aura of entrapment.

High-angled shots reappear only at the very end of the film, which closes with a crane shot of the protagonist. These shots return Veronika to the peaceful life established at the beginning of the film. The camera here serves as a deus ex machina that tries to bring the film to a happy closure and to symbolize Veronika's coming to terms with her tragedy. Moreover, the concluding highangled shot-where the camera becomes a sort of eye in the skyand the reappearance of the paternal figure (Fedor) emphasize the restoration, if only partial, of the patriarchal order that presumably will protect Veronika in the future. The protagonist's emotional state, however, hardly coincides with the camera's attempts to regain the space of innocence. In the words of Linda Williams, Cranes "begins, and wants to end, in a space of innocence."16 But Veronika never lets the old space of innocence be unambiguously restored.

\section{The Rhetoric of "Too Late"}

Mary Ann Doane points out that "the 'moving effect' of melodrama is tied to a form of mistiming, a bad timing, or a disphasure."17 Soviet home-front melodrama of the 1950s in general, and The Cranes Are Flying in particular, redefined the nature of Soviet time by

\footnotetext{
16 Linda Williams, "Melodrama Revised," 65, in Refiguring American Film Genres, ed. Nick Browne (Berkeley: University of California Press, 1998). 
foregrounding the temporality of the protagonist's losses and her powerlessness in the face of time's irreversibility. The melodramatic mistiming was a departure from the temporality of Stalinist culture, which favored a teleological vision of great historical time: the inevitable progression of history toward the triumph of communism. Existing in such a temporality, the characters were supposed to create features of the future in the present, by, for example, overfulfilling production plans and thus being several months or years ahead of schedule.

Cranes also shifted the direction of Soviet temporality; instead of overcoming the future, the film's protagonist seeks reconciliation with her past. Thaw-era melodrama shifts the focus from official state time to personal, individual time; more precisely, the film dramatizes the conflict between personal and state time. Cranes opens with a tilted shot of the frame of the clock on the Kremlin tower. This is the first visual clue to the film's concern with personal time. The narrative confirms the discrepancy between state time and the characters' personal time: at 4 a.m. on June 22, the Kremlin clock simultaneously chimes the end of Boris and Veronika's date and the beginning of war.

State time and the lovers' personal time are out of emotional tune throughout the film. Two events - the beginning of the war and the hard-won victory at its end-delineate state time. Boris and Veronika miss the official announcement of the outbreak of war because of their long rendezvous. They are also emotionally displaced vis-à-vis the moment of victory because Boris is killed and Veronika's irrecoverable loss prevents her from joining the general festivities.

Boris and Veronika are not only out of sync with state time, but also are never able to synchronize their personal times. The only moment when the lovers' personal clocks tick together is during the last morning of peace. With the outbreak of war, the rhetoric of "too late" takes over the characters' personal time. The traumatic separation of the two lovers starts with Veronika's lateness, first to the farewell party, then to the site of the recruits' departure, and culminates in the scene of Boris's death, where the last thing that Boris sees is himself arriving late to his wedding to Veronika. 
The alternative to this temporality of belatedness and loss is the temporality of new beginnings, which derives much of its symbolism from the Christian notion of resurrection. Although it does not suspend the notion of loss and lateness, this temporality provides hope for rebirth. The rebirth chronotope occurs at the center of the narrative four times in scenes of extreme emotional intensity. The first two such scenes consist of miraculous coincidences - a distinct feature of melodramatic narrative. When Veronika chooses to save the life of an orphan instead of committing suicide, the saved boy's name, improbably, turns out to be Boris. Similarly, when Veronika is betrayed by Mark she finds a note from her dead fiancé, its message articulated by his "posthumous" voiceover, wishing her a happy birthday. Boris's greetings fall not on Veronika's actual birthday, but close to Christmas Day - the moment of Veronika's spiritual rebirth.

The two miracles in Cranes are followed by two naturalized metaphors of rebirth. First, spring returns to the town where Veronika is staying during the war. Second, at the very end of the film, the cranes-birds that abandon Russia in winter-return to postwar Moscow.

By defining its dominant temporality as the personal time of the protagonist's loss and rediscovery of hope, Cranes rejects the Stalinist overcoming of the present so as to project it into the future. Veronika's personal time reasserts, in Brooks's words, "the need for some version of the Sacred and offers further proof of the irremediable loss of the Sacred in its traditional, categorical unifying form."18 Thaw-era home-front melodrama conceived of the resacralization of time as a personal reconciliation with the losses of the war.

In addition to destabilizing the structure of the nuclear family, Cranes complicates the family's hierarchy by contradictions in the construction of the father's masculinity. The major contradiction arises from the juxtaposition of the official paternity discourse of the state and the discourse of the small family's paternal authority, Fedor. Official paternity is represented most often through acoustic 
devices, especially radio announcements. Of the two central radio messages in the film, the first announces the outbreak of war (thereby linking the official discourse with war), and the second assures listeners that nothing special has happened at the frontright after the episode where Boris falls victim to enemy fire. The incompatibility between the tragedy of Boris's death and the tone of the official news lays open the contradiction between the personal experience of war and the perception offered by the radio, the mouthpiece of the state. Similarly, Stepan's official speech at the end of the film contrasts with Veronika's silent mourning. Stepan's offscreen, upbeat voice is at diametric odds with the close-ups of Veronika's wordless anguish.

Fedor, in contrast to state paternity, avoids and even ironizes the style of official speeches, as he does at the farewell dinner before Boris's departure. His paternal discourse mirrors Veronika's melodramatic sincerity, as he stumbles through his toast and resorts to tears. The closing scene shows Fedor as silent as Veronika, connecting him emotionally with her trauma of war and contrasting with the conventionality of Stepan's loud public speech.

Such a splintering of paternity affects the meaning of both the war and the family tropes. Cranes identifies the "big family" of "us" with the war forces that brutalize the individual. State paternity is part and parcel of the murderous "us," as opposed to the paternity of the small family. Home-front melodrama does not resolve the conflict between state paternity implicated in war and smallfamily paternity attempting to intercede on behalf of the victimized protagonist. It represents the conflict and suspends judgment. ${ }^{19}$ The small family with a melodramatic emotional father provided one of the first proto-private spaces as an alternative to the totalitarian national family of the Stalinist era. This space, like the protagonist, celebrates its virtue through its vulnerability and suffering.

19 Zorkaia, The Illustrated History of Soviet Cinema, 212. 


\section{FURTHER READING}

Condee, Nancy. "Veronica Fuses Out: Rape and Medium Specificity in The Cranes are Flying." Studies in Russian and Soviet Cinema 3, no. 2 (2009): $173-83$.

Cooke, Brett. "Acquaintance Rape in Kalatozov's The Cranes are Flying." In O Rus! Studia litteraria slavica in honorem Hugh McLean, edited by Simon Karlinsky et al., 69-80. Oakland, CA: Berkeley Slavic Specialties, 1995. Shrayer, Maxim. "Why are the Cranes Still Flying?" Russian Review 56 (1997): 425-39.

Woll, Josephine. The Cranes are Flying. London-New York: I.B. Tauris, 2003. [This is the most detailed study of the film.] 